\title{
IMPORTANCIA DE LA ESCRITURA EN LOS PROCESOS DE INVESTIGACIÓN CIENTÍFICA
}

$\mathrm{E}$ n el siglo XVII, muchos científicos mantuvieron los resultados de sus investigaciones en secreto con el fin de que otros no pudiesen reclamarlos como propios. Figuras destacadas de ese entonces como Sir Isaac Newton evitaban a menudo anunciar sus descubrimientos por temor a que alguien más reclamara su autoría.

La solución a este problema fue propuesta e implementada por Henry Oldenburg, el entonces secretario de la Sociedad Real de Londres, al garantizar una publicación rápida en Transacciones Filosóficas de la Sociedad Real y su apoyo oficial en caso de presentarse conflictos de autoría. Por otro lado, el señor Oldenburg fue pionero en la práctica de enviar artículos/ manuscritos a expertos que podrían evaluar su calidad. De aquí es donde surgió la actual revista científica y la práctica de la revisión por pares.

Algunas personas se preguntan por qué es importante escribir sobre resultados finales o parciales de la investigación científica. Hay muchas razones sobre la importancia de publicar los resultados de la investigación. La más primordial es que la publicación es parte integral del método científico (proceso de investigación), el cual comienza con la formulación de la pregunta de investigación y de la hipótesis, y su verificación en la práctica a través del experimento, la simulación $o$ ambos. La fase final de los procesos de investigación es la publicación de los resultados obtenidos.

Otras razones que se pueden mencionar son: las publicaciones permiten que otros investigadores utilicen los resultados y las metodologías empleadas en la investigación para cerrar brechas del conocimiento en su disciplina (creación de nuevo conocimiento). A través de las publicaciones, los investigadores o científicos ganan prestigio dándose a conocer en su respectiva comunidad científica. Esto también ayuda al reconocimiento, lo cual aumenta su reputación.

En conclusión, es importante publicar los resultados de los procesos investigativos y no guardarlos para uno mismo convirtiéndose, algún día, en obsoletos. A través de la escritura de estos resultados, podemos avanzar en la ciencia y en la tecnología, y de esa forma permitir el desarrollo sostenible de nuestro planeta.

Ramón Fernando Colmenares Quintero $\mathrm{PhD}, \mathrm{Msc}$, Jefe Nacional de Investigaciones en Ingeniería Universidad Cooperativa de Colombia ramon.colmenaresq@campusucc.edu.co 


\section{THE IMPORTANCE OF RECORDING SCIENTIFIC RESEARCH PROCESSES}

$\mathrm{M}$ any scientists of the XVII century kept the results of their investigations secret in order to avoid others claiming them as their own. Thought leaders of the time, including Sir Isaac Newton, refrained from announcing many of their discoveries in fear of third parties claiming authorship on said findings.

The solution to this problem was proposed and implemented by Henry Oldenburg, secretary of the Royal Society of London at the time, to guarantee a swift publication of the discovery in the Philosophical Transactions of the Royal Society and provide official support for authorship disputes. Mr. Oldenburg himself pioneered submitting articles and manuscripts to experts in order to assess their quality. Thus, present day scientific magazines were born and peer reviews established.

Some people question the importance of writing final or partial results of scientific research, but there are many reasons for publishing said results. One main reason is that publications are a comprehensive part of the scientific method (investigative process), which begins by formulating research and hypothesis questions, and then verifying by practice through experimentation, simulation, or both. Obtained results are published during the final stage of research.

Other reasons worth mentioning are that publications allow other researchers to use the results and methodologies of the investigation to reduce knowledge gaps in their discipline (creating knowledge). Through publishing, both researchers and scientists obtain prestige and become notorious in their particular scientific community. This also increases recognition and enhances their reputation.

In conclusion, it is of utmost importance to publish the results of research processes, instead of keeping them to oneself, and heightening the risk of them becoming outdated. By putting the results in writing, we will advance science and technology, in order to pave the way for the sustainable development of our planet. 